\title{
Krzysztof Hoffmann \\ Dziesięć sążni w dół albo dziesięć uwag \\ o płynności i głębi
}

\begin{abstract}
Hoffmann Krzysztof, Dziesięć sążni w dół albo dziesięć uwag o płynności i głębi [Ten fathoms down, or ten remarks on fluidity and depth]. „Przestrzenie Teorii” 26. Poznań 2016, Adam Mickiewicz University Press, pp. 163-173. ISSN 1644-6763. DOI 10.14746/ pt.2016.26.10.

The text is an interpretation of Stanisław Barańczak's poem From the introduction to a phrasebook. The reading of the lyric reveals a basic organizing opposition, i.e. the dichotomy of "liquidity" ("shallowness") and "depth". The final parts of the interpretation present the role of poetic language (defined through modernistic concepts) as a language that gives the opportunity to counter the aporia inherent in every act of communication.
\end{abstract}

\section{1.}

\section{Ze wstęu do rozmówek}

Celem jest mówić płynnie, choć w języku, który do końca będzie obcy. Ale co to znaczy mówić płynnie? To raczej mieć wzgląd na słuchaczy niż przełamywać sztywność tej wyschłej tektury, języka w nietutejszej gębie. Rzecz w tym, żeby pozwolić im się przemknąć jak na wodnych nartach przez sztuczny staw rozmowy, cokolwiek jest warta jej głębia po kolana; aby bez potrzeby nie hamować ich zjazdu po zjeżdżalni słów w brodzik porozumienia; gdy rozmowa będzie sportem wodnym, gdy w swoim tęponosym pędzie ledwie muśnie powierzchnię obły ślizgacz-słuch, gdy dna mu nie rozpruje kołek epitetu nieoczekiwanego albo nagła rafa zwierzenia - słowem, kiedy słowo gładko trafia na słowo i zdań fala nie podnosi grzbietu ponad dopisujące zdrowie i tę wściekłą drożyznę, i pogodę doprawdy dziś ładną, gdy mówisz to, co umiesz, nie to, co byś pragnął na chwilę was opływa płytkiej unii ciepło i w pluskaniu podmiotów, chlupocie orzeczeń nareszcie zapominasz o tym, że ruch warg 
może być nieraz - bywał nieraz - wart

coś więcej; mówić płynnie, to rozumieć, że się

nie opłaca z kimś schodzić pod powierzchnię słów

cudzej czy własnej mowy - choćbyś jak najbieglej

wiódł go przez ciemne głębie, zawsze w dole zblednie

odstraszająco piaszczyste i biedne

dno obcości, przybyszu. Godzisz się? To mów¹.

2.

Barańczak w wywiadzie: „I może nawet właśnie kontrast, napięcie pomiędzy tym, co jest na wierzchu, i tym, co pod spodem - jest w tym wszystkim najciekawsze"2.

Koncept i przebieg wiersza Ze wstępu do rozmówek jest w pierwszej chwili przejrzysty: zasadza się na nie tak rzadkim dla nowofalowej poezji lingwistycznej chwycie (mówiąc językiem formalizmu) dezautomatyzacji trwałej kolokacji. Mówiąc precyzyjniej i w kontekście wiersza Barańczaka, (1) fraza, którą można by było napotkać w rozmówkach języka obcego („celem jest mówić płynnie”), (2) wpierw staje się mechanizmem generującym metaforyczne konotacje, (3) następnie zostaje poddana pracy krytycznej na poziomie teoretyczno-filozoficznym, (4) a wreszcie - w puencie utworu - jej poetycko przetworzony sens zostaje zakwestionowany i przekształcony w uogólnione przesłanie.

Jednakowoż na każdym z tych roboczo wyróżnionych etapów tekst zwija się w sobie, staje się metatekstem ${ }^{3}$, który nie tylko problematyzuje, ale i podważa pierwszą interpretację. Wyprzedzając tok wywodu, można powiedzieć, że pogtębiona lektura okazuje się zwyczajnie albo skomplikowana, albo niemożliwa. Niniejsze odczytanie wiersza nie zmierza jednak jedynie do ukazania dekonstrukcyjnej aporii tkwiącej w każdej wypowiedzi, wręcz przeciwnie, chce odsłonić etyczny wymiar mówienia,

1 S. Barańczak, Wiersze zebrane, Kraków 2007, s. 310.

2 Post scriptum. Rozmowa Bronistawa Maja i Mariana Stali ze Stanistawem Barańczakiem, „NaGłos” 1991, nr 4, s. 97.

${ }^{3}$ Por. uwagi Beaty Przymuszały, która również zauważała „rozszerzenie znaczenia pozwala[jące] potraktować ten wiersz jako rodzaj wypowiedzi «meta»". B. Przymuszała, „Mówić plynnie...” - rytmy i zgrzyty w poezji Barańczaka, [w:] Poeta i duch wolności. Szkice o twórczości Stanistawa Barańczaka, red. P. Śliwiński, Poznań 2014, s. 187. 
który $\mathrm{z}$ ową aporią musi sobie nieustannie radzić i ją przekraczać. $\mathrm{W}$ końcowych uwagach zawarta zostanie próba zarysowania odpowiedzi, dlaczego szansą na takie przekroczenie może być język poetycki.

\section{4.}

Już sam tytuł, Ze wstępu do rozmówek, odsłania wspominaną trudność w pogłębianiu interpretacji. Rozmówki to zazwyczaj - znana każdemu, kto przynależy jeszcze do kultury druku - niewielka książeczka, która ma wyposażyć jej użytkownika w zbiór elementarnych słów i zwrotów obcego języka. O ileż łatwiej i przyjemniej być turystą w obcym państwie, gdy umiemy, posługując się językiem danego kraju, chociażby zamówić do stolika kawę. W świetle nabywania podstawowych kompetencji deklaracja, iż „celem jest mówić płynnie”, zdaje się zarówno buńczuczna, jak i na wyrost, choć można sobie wyobrazić natrafienie na nią we wstępie źle zredagowanych rozmówek. Propedeutyczny język „wstępu” załamuje się dopiero gdzieś między wersem trzecim i czwartym.

Zważywszy, że wiersz pochodzi z początkowego okresu emigracji Barańczaka (z tomu Atlantyda i inne wiersze $z$ lat 1981-1985), kontekst obcej mowy jest tu niejako samonarzucający się (zwłaszcza że padają słowa o „nietutejszej gębie”), choć rzecz jasna nie sposób utożsamić autora (wykładowcę zagranicznej uczelni, od którego wymagana jest dużo wyższa umiejętność komunikacji) z użytkownikiem książeczki zwrotów najniezbędniejszych. I rzeczywiście, wraz z rozwojem wiersza „rozmówki” nie tyle okazują się kompendium najpotrzebniejszych wyrażeń, ile ironicznym synonimem strywializowanej komunikacji. Może to ta sama ironia, o której Jerzy Kandziora w kontekście innego wiersza z tomu Atlantyda pisał, że ,jest ona w istocie regresywna, «dopada» każdego przybysza-emigranta w Ameryce i stanowi rodzaj reakcji odrzuceniowej na amerykańską normalność”" „Rozmówki” to deminutywnie skarlałe i zbanalizowane „rozmowy”, sprowadzone do kilku bezpiecznych tematów (anegdotycznego zdrowia, cen i pogody - wiersz poprzedza utwór Small talk). Płynność mówienia oznacza zdolność do wejścia w społeczne konwencje czy też komunikacyjną enkulturację.

Ale w tym samym momencie wyrażenie „wstęp do rozmówek” okazuje się metawyrażeniem, oznacza prolegomena na temat tego, co poprzedza mowę. Nie sposób wszak zarysować wyraźnej granicy pomiędzy banalnością rozmówek, niezobowiązującą konwersacją, a powagą rozmowy. Para-

4 J. Kandziora, Ocalony $w$ gmachu wiersza. O poezji Stanistawa Barańczaka, Warszawa 2007, s. 190. 
doksalność sytuacji objawia się - jak zawsze - w tym, że nie ma innego środka do przekazania treści na temat języka niż język. Wstęp jest zatem warunkiem koniecznym, który trzeba przyjąć, zgodzić się na niego, aby cokolwiek zakomunikować.

\section{5.}

Strumień metafor wyzwolony poprzez przerwanie tamy, jaką jest stałość związku frazeologicznego „mówić płynnie”, zalewa kolejne wersy tekstu. Wstępnie zostaje mu przeciwstawiona „wyschła tektura / języka” kogoś, kto jest obcy dla danej przestrzeni, społeczności, grupy, lecz szybko zostaje zneutralizowana poprzez piętrzącą się metaforykę akwatyczną. Należy zatem pozwolić słuchaczom „przemknąć jak na wodnych nartach”, pomimo tego, że rozmowa zostaje zrównana ze „sztucznym stawem”, a jej głębia (kolejny związek frazeologiczny) zostanie oceniona na poziom „po kolana”.

Jak już zauważyłem, szybko dowiadujemy się, że nie chodzi o samą umiejętność zamówienia kawy, rozmówki, ale o porozumienie się, czyli rozmowę. Jednak ta ostatnia ma stać się, zgodnie z uruchomionym mechanizmem tropicznym, „sportem wodnym”. Porozumienie jest możliwe tylko na głębokość „brodzika”, a słowa nie stawiają oporu, jak na „zjeżdżalni”. Słowa mają być „gładkie” („fala zdań” z nich zbudowana ma „nie podnosić grzbietu”), aby słuch również mógł po nich sunąć jak „ślizgacz”, którego „dnu” nie zagraża żaden „kołek” ani „rafa”.

Wreszcie metaforyka akwatyczna sięga poziomu najogólniejszego, nazywa język. „Podmioty” - jedna z podstawowych części zdania i jednocześnie fundamentalne pojęcie antropologiczne - nie są wcale poważne, ale „pluskają” (się). „Orzeczenia”, które tworzą przecież zdania, wydają mało konkretny „chlupot”. Na koniec pojawia się opozycja kluczowa. Tafla rozmowy-wody wyznacza napięcie pomiędzy „powierzchnią słów” a „ciemnymi głębiami”. Czy płynie się tak samo po powierzchni jak i pod nią?

Warto być może zaznaczyć, że moment gładkiego zlewania się językowego żywiołu dotknął również samej tkanki tekstu. Wiersz jest wierszem stychicznym, lecz nic nie stałoby na przeszkodzie, aby wyróżnić w nim siedem strof o regularnej budowie rymowej (abba, cddc itd.), z której wyłamuje się jedynie strofa ostatnia o retardacyjnie rozciągniętej konstrukcji (efffe). Tym samym upłynnienie warunków rozmowy dotknęło i budowy formalnej. 
6.

Utwór przestał zatem być - ani przez chwilę zapewne nie był - tekstem o nauce języka obcego. Wszak pada w nim ironiczne sformułowanie, że „się / nie opłaca z kimś schodzić pod powierzchnię słów / cudzej czy własnej mowy”. Wiersz wadzi się z problemem charakteryzującym każdy język, zarówno ten ojczysty, jak i nie. Nie potrzeba również wielkiej spostrzegawczości, aby zauważyć, że otwierające słowa o tym, że „celem jest mówić płynnie" składają się na prosty gest antyfrazy.

Skoro tak zdyskursywizowane i przewartościowane płynne mówienie jest umiejętnością zdegradowaną, rodzi się pytanie o to, co jest jego przeciwnością, co sytuowałoby się na przeciwnym biegunie aksjologicznym. Na poziomie leksykalnym negacją „płynnego mówienia” byłoby „mówienie z trudem”, „mówienie niepewne”, „poszukujące słów”, być może ,jąkanie się"5. Takie mówienie, które ponad potoczystość komunikacji przedkłada jej precyzję, staranność, namysł nad każdym wypowiedzeniem.

Po poetyckim przetworzeniu przez Barańczaka okazuje się jednak, że „płynnemu mówieniu” nie przeciwstawia się mówienie nie-płynne, ponieważ tak naprawdę „płynność” staje bardzo blisko wobec tego, co rozumiemy jako „płytkość”, tak jak w wyrażeniu „płytka rozmowa” (kolejna wodna metafora). Jeśli tak jest, to wartościami poszukiwanymi byłyby zgodnie z przebiegiem utworu - „pogłębienie”, „głębia”. Skoro płytka rozmówka oparta jest na normie i konwenansie (zdrowie, ceny, pogoda), nie tak daleko jej (choć z zachowaniem różnic) do bezosobowego „Się” u Heideggera, które opiera się na tym, „co przystoi, co się akceptuje i odrzuca". To przywołanie nie jest przypadkowe. Niemiecki filozof nazywał cechującą Się strategię kontroli tego, co dopuszczalne, „przeciętnością” i opisywał ją, uciekając się do znaczącej retoryki: „Wszystko, co głębokie [wyr. - K.H.], zostanie z dnia na dzień wygładzone do postaci dawno znanej. [...] Każda tajemnica straci swą moc"6.

5 O przydatności „metafory jąkania” w lekturach poezji Barańczaka pisał Piotr Bogalecki: „Jawi mi się ona jako o tyle trafna, że zawiera się w niej szerokie spektrum tematów i problemów, o jakich coraz częściej pisze się w kontekście Barańczaka: niedoskonałości i pęknięć [...], «zablokowania mowy» i «niemożności mówienia», cielesności, idiomu, a w końcu choroby, defektu ciała [...]. Pozwala też ona opisać wiele formalnych osobliwości tych wierszy, jak na przykład imitujących przejęzyczenia paranomazji, elips czy przerzutni, natrętną obecność klauzul emocyjnych i pauz”. P. Bogalecki, Niepodjęta terapia Stanistawa Barańczaka. Próba diagnozy postsekularnej, [w:] Poeta i duch wolności..., s. 70-71). Kilka stron dalej pada ważne spostrzeżenie: „dyskurs jąkały to bolesny kompromis między tym, co chciałby, a tym, co w danej chwili może wypowiedzieć" (tamże, s. 74), które bardzo mocno rezonuje ze słowami z wiersza „gdy mówisz to, co umiesz, nie to, co byśs pragnął”.

${ }^{6}$ M. Heidegger, Bycie i czas, przeł. B. Baran, Warszawa 2005, § 27, s. 163. 
Czyżby wiersz wzywał zatem do porzucenia trywialnych rozmówek na rzecz dyskursu głębi? Z jednej strony wydaje się, że odpowiedź jest jasna i nie ma w niej nic ponad niezbyt nowe utyskiwanie intelektualisty na banalizację języka ${ }^{7}$. Skoro zasada płynności głosi, że „się / nie opłaca z kimś schodzić pod powierzchnię słów", należy zaburzyć ową komunikacyjną ekonomię (wygłosy dwóch wersów zawierają znaczące przymiotniki: „warta” i „wart”) w celu rozwarstwienia mowy, przydania jej głębokości i tym samym powagi, w celu złamania paktu przeciętności.

Chwilę później padają jednak słowa, które komplikują ten prosty, dychotomiczny podział oparty na opozycji płytkość / głębia. Jest to zarazem najbardziej niejasny fragment wiersza: „choćbyś jak najbieglej / wiódł go przez ciemne głębie, zawsze $\mathrm{w}$ dole zblednie / odstraszająco piaszczyste i biedne / dno obcości”. Co oznacza aliteracyjne wyrażenie „dno zblednie”? „Zblednięcie” kojarzy się z zanikaniem (kolorów), odpływaniem (krwi z twarzy), odchodzeniem (nocy). Jednak tutaj wydaje się poddane neosemantyzacji, w której aspekt osłabiania zostaje przewartościowany i w rezultacie „zblednięcie” konotuje zjawianie się, zaistnienie w polu widzenia, przybliżanie. Dno z wiersza jest zatem w aporetycznej oscylacji pomiędzy słownikowym ujmowaniem istnienia a poetyckim przydawaniem go. Lecz raczej to nie owa niejasna ontologia przynosi przekreślenie szans na rozmowę „pogłębioną”; w większej mierze to wina faktu, iż dno jest, po pierwsze, „odstraszające”, a po drugie, jest „dnem obcości”; złowieszczo i niczym klątwa brzmi także słówko „zawsze”. Nawet jeśli nie sposób dokładnie pojąć natury zagrożenia dla głębi, w wierszu wyraźnie zostaje zapowiedziana jej porażka.

\section{7.}

Można teraz podjąć ryzyko zmierzenia się z tym, czym jest „dno” rozmówek. Po pierwsze, jest „piaszczyste” i „biedne”, po drugie, jest „dnem obcości”, po trzecie, wymusza zwrócenie się do rozmówcy (czytel-

7 Pisząc o „amerykańskich” wierszach poety, Marcin Jaworski zauważał, że „wpisuje się w szerszą postawę jednej z odmian wschodnioeuropejskiego intelektualisty na emigracji, który nie tylko ma wyrazistą opinię o kraju pochodzenia, ale i w Ameryce raczej nigdy nie zadowoli się na dobre". M. Jaworski, Implozja wiersza. O amerykańskiej poezji Stanistawa Barańczaka, [w:] Poeta i duch wolności..., s. 144.

8 Niniejsze odczytanie problematyzuje spostrzeżenie Beaty Przymuszały, że „Wiersz Barańczaka gra płynnością w jej wielorakich odcieniach, przy czym, jak zawsze, jest to gra konsekwentna”. B. Przymuszała, „Mówić plynnie...” - rytmy i zgrzyty w poezji Barańczaka, s. 186. Badaczka nie poświęca oddzielnej uwagi puencie utworu. 
nika) alienującą apostrofą „przybyszu”. A zatem ten, kto się komunikuje, ryzykuje, że na zawsze pozostanie nie u siebie, że język skaże go na wygnanie z iluzji utopijnej wspólnoty porozumienia, że każda mowa będzie mową obcą, nie dlatego, iż znajduje się w tej lub innej przestrzeni geograficznej, w takim lub innym gronie, ale ponieważ nie istnieje (nigdy nie istniała) mowa rodzima. Dno każdej rozmowy jest „biedne”, ponieważ ostatecznie język musi przywieść do komunikacyjnej porażki; z planowanego wyrażenia siebie w całym swym bogactwie zostaje ubóstwo wypowiedzenia.

I to tutaj zasadza się tragiczny paradoks diagnozowany przez wiersz. Alternatywą dla „płynnego mówienia” byłaby bowiem nie tyle próba zaproponowania innego trybu dialogu, lecz - skoro głębsza rozmowa jest niemożliwa (choć upragniona) - jego radykalna odmowa, czyli... milczenie. Ten, kto nie godzi się na miałkość codziennej komunikacji, nie dysponuje zarazem (w codzienności) żadną mową uświęcającą dialog, winien tedy go nie rozpoczynać. Niczym w słynnym aforyzmie Wittgensteina, dopóki istnieje ryzyko ugrzęźnięcia na konwersacyjnej mieliźnie, dopóty winno się milczeć.

\section{8.}

Utwór kończy się jednak jednosylabowym imperatywem, jedynym czasownikiem w trybie rozkazującym, „mów”. Gdyby nie płytkość porównania, można by zadać pytanie, iż skoro Pan Cogito pozostawił po sobie jedno ostatnie słowo, „idź”, jakież inne może przekazać w swym wygłosie lingwistyczny wiersz? Mówienie zostaje obwarowane jednak warunkiem „Godzisz się?”. Można go rozwinąć w pseudosylogizm: (a) chcąc uczestniczyć we wspólnocie („unii ciepło”), trzeba się komunikować; (b) każdy akt komunikacji skazany jest na brak zadowalającej głębi, czyli porażkę; (c) bycie z innymi jest więc przewrotną zgodą na jednoczesne ryzyko wywłaszczania, alienacji. Oto jak ujawnia się etyczny pierwiastek wiersza o odrobinę kolistej strukturze: choć biedne dno dialogu może zjawić się o wiele szybciej i gwałtowniej niż przypuszczaliśmy, mówienie jest (odważną?, konieczną?, heroiczną?) akceptacją takiego stanu rzeczy. Kolistość argumentacji (tekst pochodzi Ze wstępu do rozmówek, co w niniejszej lekturze chciałem odczytywać jako warunek każdej mowy) oznacza, że słowa wiersza odnoszą się również do niego samego; metawiersz zawiera zatem stwierdzenie, że podejmuje się ryzykownej gry w rozmowę, pomimo tego, że grozi mu wypłaszczenie jego znaczeń. 
I gdyby zatrzymać lekturę w tym miejscu, z pewnością tak by się stało. Co nie oznacza, że kontynuacja daje jakąkolwiek gwarancję uniknięcia raf interpretacyjnych. Warto jednak zauważyć, że tekst subtelnie zawiera dwa momenty, które mogą stanowić punktowe zaburzenie (choć nie przeciwwagę) „płynności mówienia”. Opowiedzieć się za ich poszukiwaniem jest równoznaczne z przyznaniem im przymiotów etyczności znamionujących (jak podpowiada wiersz) każdy gest komunikacji, który podejmuje ryzyko rzucenia się na głębokie wody (albo choćby głębsze).

Owe dwa momenty to zagęszczenia $\mathrm{w}$ toku wiersza językowej materii, które urzekają swą jednoczesną delikatnością. Pierwsze zawiera się w charakterystyce „obłego ślizgacza-słuchu”, którego w zaskakujący sposób ma cechować „tęponosy pęd”. Drugi moment to stematyzowanie tego chwytu - dno ślizgacza ma uniknąć rozprucia przez „kołek epitetu”, ale przerzutnia dodaje jeszcze „nieoczekiwanego”. Tak samo jak przymiotnik „nieoczekiwany” staje się nieoczekiwanym (przerzuconym do nowego wersu) epitetem słowa „epitet” (jest jednocześnie tezą i egzemplifikacją tej tezy; „epitet byłby w tym przypadku synekdochicznym wskazaniem na język poetycki”9), tak też słuchowi zmetaforyzowanemu do postaci ślizgacza zostaje przypisany burzący logikę przenośni „tęponosy pęd”. W pierwszej chwili zdawać by się nawet mogło, że „tęponosy pęd” jest skrajnym przypadkiem nieoczekiwanego epitetu, przypomina bowiem neologizm. W istocie „tęponosy” to zoologiczne określenie gatunkowe, przymiotnik pojawia się przy nazwie nosorożca białego. Spiętrzone (jak fala) warstwy znaczeń uruchomione przez nieoczekiwany epitet faktycznie bezlitośnie rozrywają $\mathrm{w}$ tym momencie dno interpretacji: ślizgacz, słuch i nosorożec, a zatem łódź motorowa, jeden ze zmysłów i afrykańskie zwierzę tworzą szereg, który nie daje się sprowadzić do zgrabnej, okrągłej formuły. Sensy każdego z leksemów nie sumują się ani nie mnożą, wytrącają za to z gładkiej (i płytkiej) lektury.

I pewnie nie będzie w tym momencie zaskoczeniem stwierdzenie, że w ten sposób pojawia się sugestia, jakie szanse na zbawienie Barańczak upatruje wobec płytkości „rozmówek” - jest nią poezja. Pomimo tego, że w każdym geście komunikacji czai się ryzyko, iż rozmowa (sensu largo)

9 Tamże. W tym miejscu interpretacja przeprowadzona przez Przymuszałę i moja jej próba spotykają się. Warto jednak zauważyć, że o ile badaczkę interesują bardziej „zgrzyty" w płynności, niniejsze odczytanie sięga do kategorii wywiedzionych z immanentnej lektury tekstu i zmierza ku innym wnioskom. Te dwie lektury są raczej komplementarne niż polemiczne (z niewielkimi wyjątkami). 
osiądzie na mieliźnie, nie tylko nie osiągnie swojego celu, ale i energia $\mathrm{w}$ nią zainwestowana zostanie zmarnowana, to etyczny przymus mówienia wiąże się z pragnieniem poszukiwania głębi, tj. tej warstwy porozumienia, która będzie się przeciwstawiać codziennej banalności. Język poetycki nie jest wolny od ogólnych warunków wymiany symbolicznej, zdarza mu się jednak działać jako ich paliatyw. Poprzez mechanizmy, których umiejętność rozpoznawania przynależy do repertuaru sposobu czytania poezji, oferuje możliwość chwilowego uśmierzenia powierzchowności międzyludzkiej egzystencji i otwiera ją na przygodę ( $w$ dowolny sposób rozumianej) głębi.

\section{0.}

Nagromadzenie metaforyki akwatycznej oraz krytyka opisywanej za jej pomocą kondycji rzeczywistości międzyludzkiej mogłaby zrodzić chęć przywołania myślicieli posługujących się podobnym językiem. Rzecz jasna z Zygmuntem Baumanem i jego konceptem „płynnej nowoczesności” na czele (w końcu „celem jest mówić płynnie”). W fundacyjnej dla pojęcia książce socjolog wymieniał wiele językowych przymiotów, które charakteryzują nową epokę: „Płyny łatwo się przemieszczają. «Płyną», «rozlewają się", "wypływają", "wychlapują się», "przelewają", "ciekną», "zalewają», «pryskają», «kapią», «sączą się», «wyciekają». W przeciwieństwie do ciał stałych niełatwo je powstrzymać"10. Nietrudno zauważyć, że wiele z wymienionych czasowników wchodzi w kolokacje językowe, którymi można określać też komunikację: rozmowa może płynąć, pewne dane wypływają, ktoś może wychlapać sekret, można zalać rozmówcę argumentami albo można sączyć zdania, wycieki (albo przecieki) informacji też nie są niecodziennością. Bauman stwierdza, że „właśnie «płynność» albo «ciekłość» można uznać za trafne metafory, oddające istotę obecnej, pod wieloma względami nowej, fazy w historii nowoczesności"11. Płynność nie tylko staje się kategorią opisową epoki historycznej, sięga głębiej, do warunków egzystencji, które podobnie zostają opisane za pomocą języka morskiej podróży: „Płynne życie [...] nie potrafi zbyt długo zachować swego kształtu ani utrzymać stabilnego kursu"12. Czyżby zatem Barańczak zbliżał się - poprzez sięgnięcie do zbliżonego obrazowania - do wizji Baumana?

\footnotetext{
10 Z. Bauman, Plynna nowoczesność, przeł. T. Kunz, Kraków 2006, s. 6.

11 Tamże, s. 7.

12 Z. Bauman, Plynne życie, przeł. T. Kunz, Kraków 2007, s. 5.
} 
Wydaje się, że odpowiedź twierdząca oznaczałaby nieuzasadnione „postmodernizowanie” światopoglądu Barańczaka. Mimo wszystko Bauman przeciwstawia płynność temu, co stabilne, bezpieczne, trwałe. Mniej interesuje go sam język, bardziej natomiast społeczna rzeczywistość i przemiany kulturowe. Tymczasem Barańczak w swym wierszu jednoznacznie odwołuje się do sytuacji komunikacyjnej. Opozycją nie jest płynność / stałość, ale płytkość / głębia. W gruncie rzeczy, Barańczakowi chodzi o sposób wartościowania naszych zabiegów budowania sensu, tj. o postawę hermeneutyczną.

W większym stopniu do Barańczaka przystaje diagnoza sformułowana przez Hansa Ulricha Gumbrechta. Teoretyk literatury przy okazji utyskiwania na „niekwestionowaną w ramach instytucji humanistyki centralną pozycję, jaką zajmuje interpretacja”, stwierdzał, że interpretacja

opiera się na pozytywnej wartości, jaką nasze języki właściwie automatycznie wiążą z wymiarem „głębi”. Jeśli nazywamy jakąś obserwację „głęboką”, zamierzamy pochwalić ją za to, że nadała zjawisku nowe, bardziej złożone, szczególnie adekwatne znaczenie. Coś, co uznajemy za „powierzchowne”, jest natomiast pozbawione tych wszystkich cech, ponieważ sugerujemy, że nie zdołało sięgnąć „poza” albo „pod” pierwsze wrażenie wywołane przez dane zjawisko (na ogół nie wyobrażamy sobie, by cokolwiek lub ktokolwiek nie chciał mieć głębi) ${ }^{13}$.

Dla Gumbrechta taki stan rzeczy stanowi powód, aby sprzeciwić się prymatowi postawy hermeneutycznej w naukach humanistycznych charakterystycznemu dla całej, szeroko rozumianej formacji nowoczesnej, w niniejszej lekturze wiersza ważne jest jednak co innego. Twarde obstawanie przy dialektyce płytkości (powierzchowności) i głębi świadczy o przywiązaniu Barańczaka do paradygmatu modernistycznego, niesionych przez niego wartości i modeli interpretacyjnych. Również dlatego poezja ma szansę „sięgnąć głębi” - modernizm można wszak rozumieć jako ostatnią epokę, która w to szczerze wierzyła.

\section{BIBLIOGRAFIA}

Barańczak S., Wiersze zebrane, Kraków 2007.

Bauman Z., Plynna nowoczesność, przeł. T. Kunz, Kraków 2006.

Bauman Z., Ptynne życie, przeł. T. Kunz, Kraków 2007.

${ }^{13}$ H.U. Gumbrecht, Production of Presence: What Meaning Cannot Convey, Stanford 2004, s. 21. Cytowany fragment pochodzi z przygotowywanego przekładu książki (przeł. K. Hoffmann, W. Szwebs). 
Bogalecki P., Niepodjęta terapia Stanisława Barańczaka. Próba diagnozy postsekularnej, [w:] Poeta i duch wolności. Szkice o twórczości Stanisława Barańczaka, red. P. Śliwiński, Poznań 2014.

Gumbrecht H.U., Production of Presence: What Meaning Cannot Convey, Stanford 2004.

Heidegger M., Bycie i czas, przeł. B. Baran, Warszawa 2005.

Jaworski M., Implozja wiersza. O amerykańskiej poezji Stanistawa Barańczaka, [w:] Poeta i duch wolności. Szkice o twórczości Stanisława Barańczaka, red. P. Śliwiński, Poznań 2014.

Kandziora J., Ocalony w gmachu wiersza. O poezji Stanisława Barańczaka, Warszawa 2007.

Post scriptum. Rozmowa Bronisława Maja i Mariana Stali ze Stanisławem Barańczakiem, „NaGłos” 1991, nr 4.

Przymuszała B., „Mówić plynnie...” - rytmy i zgrzyty w poezji Barańczaka, [w:] Poeta i duch wolności. Szkice o twórczości Stanisława Barańczaka, red. P. Śliwiński, Poznań 2014. 
